\title{
Multiple Deprivation and Urban Development in Athens, Greece: Spatial Trends and the Role of Access to Housing
}

\author{
Nikos Karadimitriou ${ }^{1, *(D)}$, Thomas Maloutas ${ }^{2}$ (D) and Vassilis P. Arapoglou ${ }^{3}$ (D) \\ 1 Bartlett School of Planning, UCL, 14 Upper Woburn Place, London WC1H 0NN, UK \\ 2 Department of Geography, Harokopio University, 70 El. Venizelou Str, 17671 Athens, Greece; \\ maloutas@hua.gr \\ 3 Department of Sociology, University of Crete, 74100 Rethymno, Greece; arapov@uoc.gr \\ * Correspondence: n.karadimitriou@ucl.ac.uk
}

check for updates

Citation: Karadimitriou, N.;

Maloutas, T.; Arapoglou, V.P.

Multiple Deprivation and Urban Development in Athens, Greece: Spatial Trends and the Role of Access to Housing. Land 2021, 10, 290.

https://doi.org/10.3390/land10030290

Academic Editor: Jefferey M. Sellers

Received: 2 February 2021

Accepted: 9 March 2021

Published: 12 March 2021

Publisher's Note: MDPI stays neutral with regard to jurisdictional claims in published maps and institutional affiliations.

Copyright: (c) 2021 by the authors. Licensee MDPI, Basel, Switzerland. This article is an open access article distributed under the terms and conditions of the Creative Commons Attribution (CC BY) license (https:// creativecommons.org/licenses/by/ $4.0 /)$.

\begin{abstract}
This paper presents the spatial distribution of multiple deprivation in Athens, and links these spatial patterns to the city's urban development trajectory and the way housing is accessed. Multiple deprivation was measured as the combined concentration of disadvantageous employment situation, access to education and housing conditions. A principal components analysis was utilized for 20 variables from the three said domains. Two components were identified as statistically significant. The analysis covered approximately 3000 urban spatial analysis units (URANU), using data from the population censuses of 1991, 2001 and 2011. The findings unveil that from 1991 to 2011, multiple deprivation in the urban periphery as well as in city center areas worsened. Conditions in many (but not all) working-class areas in the west of Athens, as well as in middle class suburbs in the east, improved or did not get worse. If compared to the urban development trajectory of the city, this distribution means that the historical East-West socio-economic division is getting less pronounced, whereas an important center-periphery dynamic is emerging. The filtering and sorting process of the housing market could explain those trends. It appears that the most affected populations are those outside the Greek family-centered and homeownership-based model of access to housing.
\end{abstract}

Keywords: multiple deprivation; Athens; urban development; housing

\section{Introduction}

This paper sets out to understand the spatial distribution of multiple deprivation in Athens and its evolution through time. There is no established approach to measuring multiple deprivation in Greek cities (and even more so, no dedicated observatory). The relatively scarce existing research on multiple deprivation in Athens means that the paper presents a newly developed method to measure multiple deprivation, which can effectively utilize census data spanning a period of 30 years. It is the comparison with the urban development trajectory of the city and with the way housing has historically been accessed that provides an explanation for the spatial patterns of deprivation. In the following paragraphs, the paper will present the key characteristics of the urban development trajectory of the city and the theories which could be used in order to understand the social relations underpinning that trajectory.

Athens' urban development trajectory has historically combined expansion with the intensification of land exploitation. Real estate development in the late 1990s and early 2000s, just before and shortly after Greece entered the eurozone, was fueled by cheap bank credit channeled into housebuilding [1]. From an urban development perspective, this meant that several outer suburbs of the city grew in population and densified, especially in areas close to the major new transport infrastructures (mainly motorways) that were built during that period [2]. The flip side of this urban development trajectory was the steady exodus of the Greek middle and upper social strata from overbuilt areas in the city center and its surrounding belt, which begun in the 1970s [3,4]. 
Although the effects of negative externalities on the quality of life of Athens' residents, as well as problems of decline in the urban core, have been of concern to the public at least since the 1980s, the main preoccupation of strategic planning in the city, up to the 1990s, was to manage growth and to promote a more decentralized metropolis. This was done in an effort to counter-act what was perceived to be an undesirable centripetal city dynamic. That is a core theme of metropolitan plans like the Athens Regulatory Plan of 1985 [5]. The promotion of a more decentralized urban structure is also a key theme of the 1992 revision of that plan, albeit at that point in time the city's population had virtually stopped growing, but the urban fabric continued to expand outward (see Figure 1).

Many city-center neighborhoods, whose populations, rents and prices dropped, offered relatively affordable housing options to successive waves of immigrants who entered the country in the early 1990s after the dissolution of the Eastern Block, and subsequently (in the 2000s) from African and Asian low-income countries. These groups accessed housing initially as tenants and then, some of them, as homeowners [6], predominantly in the lower floors of apartment blocks in central areas [7].

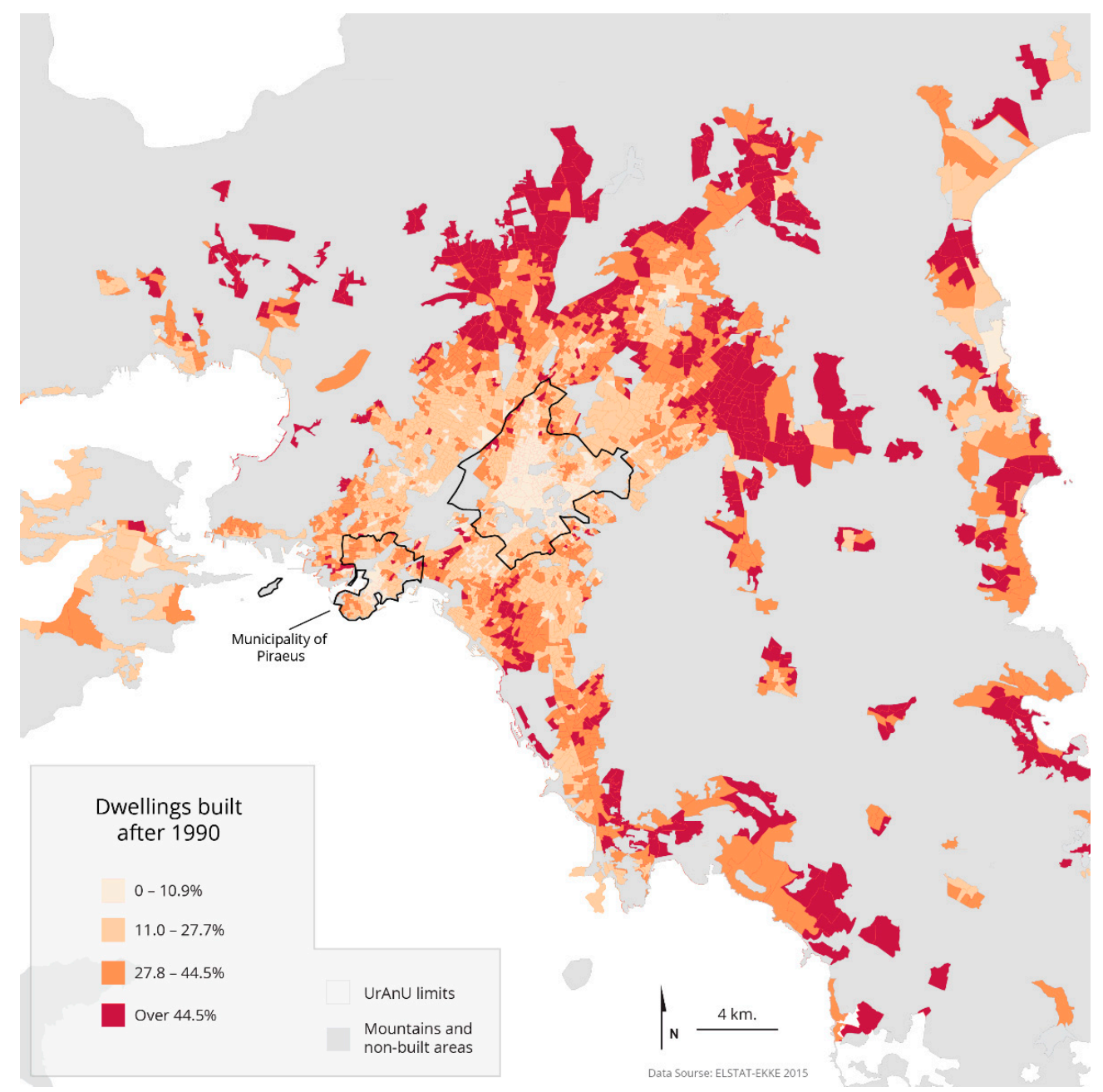

Figure 1. Age of dwelling stock: Percentage of dwellings built after 1990 by URANU (2011). Source: [8].

Access to housing is one of the key parameters affecting social inclusion, especially so in southern Europe where housing played a key role in the social integration of internal urban migrants [9,10]. Arbaci [9] and Kandylis [11] explain how foreign immigrant populations in southern European cities-in contrast to native internal migrants of the early post-war period-face residential marginalization even though they may be eco- 
nomically integrated. Arbaci [12] argues that the housing provision systems and the area-based urban policies in said countries are structurally incapable of addressing this problem. Insofar as the role of the State in dealing with issues of social cohesion is concerned, D' Ambrosio et al. [13] distinguish between three approaches: the "French", the "Anglo-Saxon" and the "monopoly". The "monopoly" approach distinguishes between "insiders" and "outsiders", depending on the access of social groups to the (State) mechanisms of redistribution. Special interest group control over institutions aiming at resource (re)allocation is a key concern for this approach. Social cohesion drops when action to prevent the hijacking of institutions fails, yet the cohesion of groups with access to resources increases, leading to factionism (for a more detailed account, see Arapoglou et al. [14]).

In the case of Greece, the "monopoly" approach has frequently been employed to explain the role of the State. According to Tsoulouvis [15], the Greek State facilitates the "soft budgeting" strategies of Greek households and plays a key role in creating and distributing value by means other than the operation of transparent market and welfare systems. Karadimitriou and Pagonis [16] show how valorizing real property via the allocation of development rights and via the use of public investment is a key political goal of that regime.

In Greece, the distribution of real property rights has underpinned the relationship between citizens and the State ever since the Greek state was founded. Maloutas [17] discusses how land distribution has consistently been a key ingredient in the efforts of the state to legitimize its existence and assert its authority. The standard response of the Government to major socio-economic crises since the founding of the Greek state has been to create a framework within which citizens could try to solve their problems by themselves. Within this context, homeownership and socially diffuse real property ownership became the main vehicle for the economic, social and political integration of Greek refugees in the 1920s and internal migrants later on [18]. Rent-seeking behavior from "insider" social groups in exchange for their continuing support for the political regime was tolerated, if not promoted, by governing parties throughout the post-war period [17], and ardently supported by the US in the aftermath of the war [19].

The public debt crisis which took hold after 2008/2009 was a sharp shock to the city's urban development trajectory, and brought issues of access to housing, poverty and deprivation to the forefront. However, in a context of austerity and slow economic growth, policies to address those emerging issues have not necessarily been as successful as one would have hoped. Research on the geography of deprivation in the city is only recently beginning to attract attention as a topic of interest $[20,21]$. In parallel to this trend, there is a much longer tradition of exploring segregation in Athens [12,22,23], as well as its links to housing and welfare provision in the broader context of southern Europe $[9,10,12]$. This paper will estimate and map the spatial distribution of multiple deprivation in Athens, and will link its spatial patterns to the urban development trajectory of the city and the way housing is accessed by the city's residents.

The exploration of multiple deprivation will be contextualized within the urban development model of the city. Following the introduction, Section 2 explores the methodology used for the measurement of multiple deprivation in Athens, whereas Section 3 discusses Athens' urban development model and its implications for access to housing, maps the results of this analysis, and discusses its findings. Finally, Section 4 draws key conclusions and highlights potential policy directions.

\section{Materials and Methods}

The approach followed in the paper is aligned toward Townsend's understanding of deprivation as a phenomenon inextricably tied to poverty. According to this view, deprivation derives from a lack of resources such as income, and covers a wide gamut of living standards [24]. The critique to this approach has to do with the way deprivation indicators are arrived at, and the suitability of an approach based on a limited set of indicators for present-day society. That critique triggered a debate about the nature of 
poverty and of social exclusion, as well as about the way they could be measured [25]. Out of that debate emerged an understanding that deprivation is a useful concept when it comes to measuring non-monetized aspects of poverty.

This paper utilizes the concept of "relative" deprivation in order to measure deprivation in Athens. However, in Greece, there is no equivalent to the PSE Survey, or the UKLHS [26-28] or PSENI [29], and therefore it is not possible to rely on such established work in order to devise suitable measurements of "perceived" deprivation. However, the paper follows the logic of the UK Communities and Local Government framework, whereby measuring deprivation relies on establishing "distinct domains of deprivation which can be recognized and measured separately. People may be counted in one or more of the domains, depending on the number of types of deprivation that they experience." [30]

According to Nolan and Whelan [31], it is important to utilize both monetary and non-monetary indicators in order to measure deprivation. They highlight the key role of non-monetary indicators in measuring people's ability "to participate" and the "financial resources" available to them [31]. They use a factor analysis of the European Community Household Panel (ECHP) survey's parameters to identify 5 dimensions of deprivation [31]:

- Basic life-style deprivation-inability to afford basic goods and services;

- Secondary life-style deprivation —inability to afford goods such as a car, a phone, a color television;

- Housing facility deprivation-not having a bath or shower, an indoor flushing toilet and hot and cold running water;

- Housing deterioration — encountering problems such as a leaking roof, etc.;

- Environmental problems-encountering problems such as noise, pollution, vandalism and inadequate space and light.

Nolan and Whelan also used European Union Statistics on Income and Living Conditions (EU-SILC) data, which are more limited, to derive 3 deprivation dimensions [31] (pp. 312-313):

- Consumption deprivation;

- Household facilities;

- Neighborhood environment.

The variables related to deprivation in Athens, which are available via the census, are limited in number and scope. Therefore, the dimensions of deprivation coming out of the analysis are also limited in number, and less diverse. The Hellenic Statistical Authority (ELSTAT) population census data for 1991, 2001 and 2011 cover approximately 3000 urban spatial analysis units (URANU). These three datasets cannot support the identification of deprivation related to lifestyle/consumption or to the neighborhood environment. Moreover, data on social and family networks and more broadly on mutual support are also not available, and therefore this paper could not take such parameters into account. The data available pertain to housing/household facilities, and to consumption deprivation assumed by resource poverty (employment and education).

The paper utilizes a simple but innovative methodological approach in an attempt to measure multiple deprivation in the Greek context. It uses data from the 1991, 2001 and 2011 national censuses to estimate deprivation as a composite outcome of several factors. These factors are related to inclusion/exclusion from the economically active population and from education, as well as positioning within the occupational, the educational and the housing hierarchy (basic amenities, lack of space, tenure and position within apartment blocks) (Table 1). Other than housing, the domains of education and employment are two crucially important social resources, the level of access to which is a key component of deprivation. Therefore, our exploration is limited to the factors potentially leading to deprivation and not to the actual deprivation conditions experienced in particular areas and perceived by their population. Unemployment, unskilled occupations and education are significant dimensions of deprivation since its inception by Townsend, and are included in the English index of deprivation and in most recent attempts of measuring deprivation 
in European cities. In the Greek context, these are also especially significant for two reasons. First, because we want to explore whether job redundancies and unemployment have affected some areas disproportionately to others. Second, because education has historically been a vital factor for security and social mobility for Greek households.

Table 1. Deprivation variables.

\begin{tabular}{|c|c|c|c|}
\hline Domain & $\begin{array}{c}\text { Composite Variables } \\
\text { (PCA *) }\end{array}$ & Label & $\begin{array}{c}\text { Constitutive Variables (Percentage } \\
\text { of } \operatorname{Var}_{i} \text { by URANU }{ }^{* *} \text { ) }\end{array}$ \\
\hline \multirow{4}{*}{ Employment } & Structural inactivity & Empl1 & $\begin{array}{l}\text { Var1: economically inactive } \\
\text { Var2: women homemakers }\end{array}$ \\
\hline & $\begin{array}{l}\text { Chances of access to } \\
\text { employment }\end{array}$ & Empl2 & $\begin{array}{l}\text { Var3: unemployed } \\
\text { Var4: young unemployed 15-34 } \\
\text { Var5: mature unemployed 50-64 }\end{array}$ \\
\hline & Role models (lack of) & Empl3 & $\begin{array}{l}\text { Var6: managers and professionals } \\
(30-64)\end{array}$ \\
\hline & $\begin{array}{l}\text { Quality of } \\
\text { employment }\end{array}$ & Empl4 & Var7: routine occupations \\
\hline \multirow{3}{*}{ Education } & Education level (high) & Edu1 & $\begin{array}{l}\text { Var8: } 20-64 \text {-year-olds with higher } \\
\text { education }\end{array}$ \\
\hline & Education level (low) & Edu2 & $\begin{array}{l}\text { Var9: } 20-64 \text {-year-olds with up to } \\
9 \text { years of education }\end{array}$ \\
\hline & Education dynamic & Edu3 & $\begin{array}{l}\text { Var10: } 15-18 \text {-year-olds not in } \\
\text { education } \\
\text { Var11: } 19-27-y e a r-o l d s \text { not in } \\
\text { education }\end{array}$ \\
\hline \multirow{4}{*}{ Housing } & $\begin{array}{l}\text { Extremely negative } \\
\text { housing conditions }\end{array}$ & Hous1 & $\begin{array}{l}\text { Var12: population in irregular } \\
\text { dwellings } \\
\text { Var13: population in dwellings } \\
\text { without heating }\end{array}$ \\
\hline & $\begin{array}{l}\text { Lack of housing space } \\
\text { and vulnerability }\end{array}$ & Hous2 & $\begin{array}{l}\text { Var14: population in dwellings with } \\
<20 \text { sq } \mathrm{m} / \text { capita } \\
\text { Var15: tenants in }<20 \text { sq } \mathrm{m} / \text { capita } \\
\text { Var16: routine occupations living in } \\
<20 \mathrm{sq} \mathrm{m} / \text { capita } \\
\text { Var17: unemployed in } \\
<20 \mathrm{sq} \mathrm{m} / \text { capita }\end{array}$ \\
\hline & $\begin{array}{l}\text { Tenure and } \\
\text { vulnerability }\end{array}$ & Hous3 & $\begin{array}{l}\text { Var18: population in rented } \\
\text { dwellings } \\
\text { Var19: routine occupations among } \\
\text { tenants } \\
\text { Var20: unemployed among tenants }\end{array}$ \\
\hline & Low amenity *** & Hous4 & $\begin{array}{l}\text { Var21: population living in basement } \\
\text { or ground floor apartments }\end{array}$ \\
\hline
\end{tabular}

* Principal Component Analysis. ${ }^{* *}$ Urban analysis unit. Spatial units with an average population of 1200 based on ELSTAT's 2011 census tracts. Approximately 3000 units harmonized for the censuses of 1991, 2001 and 2011. $* * *$ available only for 2011.

The three domains (employment, education and housing) were divided into different sub-domains (PCA variables in Table 1) according to the available relevant variables within each domain. The employment domain is divided into (1) structural inactivity, measured by the percentage of the economically inactive population and of women homemakers; (2) chances of employment, measured by the percentage of general unemployment and of unemployment regarding specific age cohorts; (3) lack of role models, measured by the relative absence of higher occupational categories; (4) quality of employment, measured by the specific weight of routine occupation jobs. The education domain is divided into 
(1) higher and (2) lower education level, measured respectively by the specific weight of their relative percentages in the adult population, and (3) education dynamic, measured by the percentage of dropouts in upper secondary education and the percentage of those not in education for the age cohort corresponding to most of the post-secondary, higher and post-graduate educational channels. Finally, the housing domain is divided into (1) extremely negative conditions, measured by the percentage of those living in irregular housing units and those with no heating; (2) lack of housing space and vulnerability, measured by the percentage of those living in dwellings smaller than $60 \%$ of the median among the entire population, but also among tenants, holders of routine jobs and the unemployed; (3) tenure and vulnerability, measured by the percentage of tenants in the entire population, but also among holders of routine jobs and the unemployed, and (4) low amenity, measured by the percentage of those living in basements and on ground floors within apartment blocks (Table 1). The three domains (employment, education and housing) were given almost equal importance, since each of them participates in the analysis with either three or four composite variables

Initially, deprivation indices were calculated in a simple step-by-step way for each of the three domains and as a whole for each of the three census dates, covering all initial deprivation variables. Values for each variable were standardized, whereby higher values were assigned to each measurement according to the distance from the mean, in standard deviation multiples. The rationale behind the decision to attribute values unequally is to single out the areas where values indicating higher deprivation are maximized. In more detail, for an initial value $\chi$, a value of 1 was assigned for $\chi<$ mean, a value of 2 was assigned for mean $<\chi<$ mean +0.5 stdev, a value of 3 was assigned for mean $+0.5<\chi<$ mean +1 stdev, a value of 5 was assigned for mean +1 stdev $<\chi<$ mean +2 stdev, and a value of 7 was assigned for mean +2 stdev $<\chi$. Eventually, a deprivation index was calculated for each domain (e.g., Deprivation Employment Index $=($ Empl1 + Empl2 + Empl3 + Empl4) $/ 4)$ and for each year, and finally a General Deprivation Index (GDI) = Deprivation Employment Index+ Deprivation Education Index+ Deprivation Housing Index with a minimum value of 3 and a maximum of 21 .

Multivariate statistical techniques were used to provide an estimation of deprivation for Athens in 1991, 2001, and 2011. This measurement also involves the exploration of the spatial dimensions of deprivation and, eventually, the mapping of the spatial patterns of said deprivation estimates in Athens, to reveal the dynamics shaping the city's socio-spatial landscape during these 20 years (1991-2011).

\section{Results and Discussion}

Immediately after the end of the civil war in 1949 and for two consecutive decades, internal migration to Athens (and several other urban centers) created demand for housing but also provided cheap construction labor. The city geographically expanded, whereas housing supply mainly came in the form of medium-height apartment blocks provided via the "land for flats" (antiparochi) barter system [15,22,32], although self-promotion and selfconstruction were also widespread. From the early 1950s to the late 1970s, 34,000 apartment blocks were built in Athens [7]. Athens' population more than doubled between 1950 and 1980, and the city densified, as its mostly low-density neoclassical-style building stock was replaced by five- to seven-story modernist blocks of flats, which also sprawled into the previously unbuilt land further away from the Athens-Piraeus historical urban core (Figure 2). This urban development model was able to quantitatively address housing need and to support several decades of economic growth. The stock produced during this period accommodated the needs of a diverse range of household sizes and incomes at various stages in their lifecycles. 


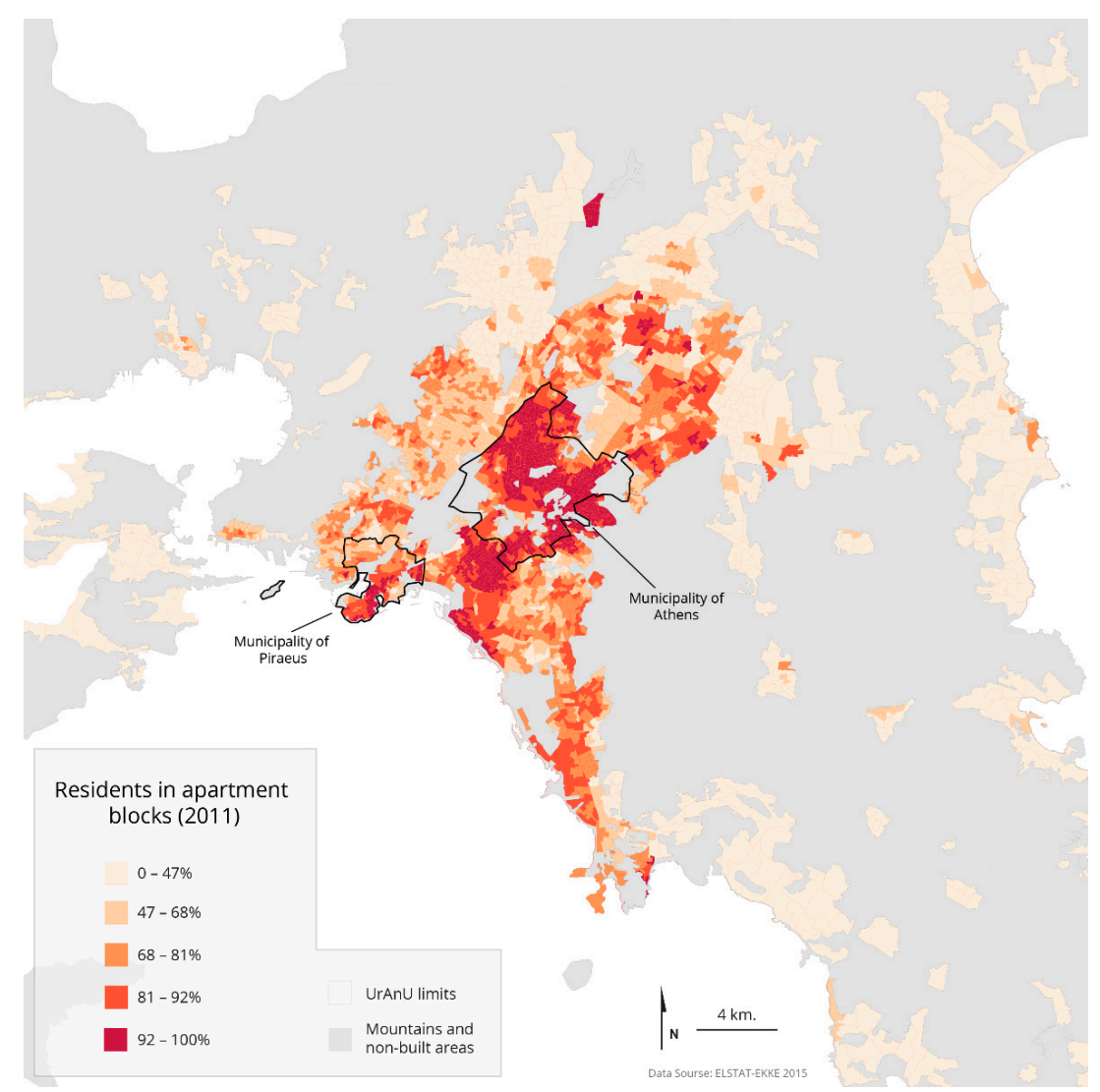

Figure 2. Percentage of residents living in apartment blocks, in the Athens metropolitan area, by URANU (2011).

It was during that period when the industrialization of the Greek economy peaked, which also left its mark on the city fabric in the form of industrial clusters along the Athens-Piraeus route, as well as along the motorways linking Athens to the north and the southwest of the country [33]. Areas comprising blue-collar socio-economic categories developed in the west and northwest of the metropolis, whereas the east and southeast evolved into white-collar areas. Much of the exurban space had poor accessibility and remained agricultural almost until the mid-1990s. In the 1980s, the spatial expansion of the city continued apace, but the population of the city stabilized and large numbers of people from white-collar intermediate or high-income socio-economic categories started to move out of the city center, where they were over-represented until then [3,34]. This form of suburbanization, which continued well into the 2000s as transport infrastructure expanded, consolidated the socio-economic profile of north and southeastern metropolitan Athens, and expanded the metropolis well beyond the Attica basin (i.e., the area between the Hymettus and Parnitha mountains and the Saronic gulf). The Olympic Games favored the more affluent areas and introduced limited pressures for gentrification in some central areas [35]. Athens' dense urban fabric also means that most of the population lives in blocks of flats (Figure 2). In some city-center areas, plot coverage exceeds $95 \%$ and the plot ratio is higher than 7. This intensive and extensive model of urban development has slowed down since the 1990s and it literally froze when the crisis occurred, as new residential construction permits dropped by 96\% from 39.956 in 2006 to 1.476 in 2016 [36].

A less pronounced suburbanization trend occurred in western Athens. The inner western suburbs were the traditional residential location of the native working class, where social mobility remained much more spatially fixed compared to eastern Athens, while the strata that moved further outward were composed of less skilled and lower income households [37]. The inflow of people from the Balkans and Central and Eastern Europe in the early 1990s, and from Asia and Africa in the 2000s, repopulated and revalorized the 
substandard dwelling stock in central areas of the city [7,38], but diverse migrant groups inhabited marginal spaces on the city periphery as well [39].

Those locational preferences were influenced by the intergenerational family-based housing access strategies of Greek households $[10,40]$, as well as by the typology of the housing stock [23]. This approach to housing access enables and incentivizes different generations of the same family to live in close proximity to each other. A dwelling stock of multistory apartment blocks comprising a diverse quality range also offers multiple housing options, which in turn facilitates the socioeconomic integration of newcomers into the city.

Economou [41,42] highlights that the consistent and persistent promotion by the Greek state of a "hands-off" approach to urban development reflected a comprehensive but unofficial housing policy with significant welfare and political implications. Formal urban planning policies and institutions played a residual role, and did not explicitly acknowledge the redistributive dimension of urban development.

Tsoulouvis [15] neatly captures the severe environmental consequences of Athens' urban development model. Inadequate provision of infrastructures and services, and degraded if not altogether depleted natural resources, result in significant drops in quality of life, as areas quickly become saturated and overbuilt. Although high-density urban environments facilitate more efficient public transport and social infrastructure provision, it took several decades for that infrastructure to be provided. In a later paper, Tsoulouvis [43] identified two socially excluded groups in the 1990s: the first group includes workers hit by long-term unemployment due to de-industrialization together with unemployed young workers looking for their first job; migrants and refugees constitute the second group. He argues that spatial patterns of social exclusion make up a mosaic across the city and take a novel form: socially excluded population groups, either the long-term unemployed or the immigrants and refugees, are concentrated in small pockets, which are not easy to demarcate precisely.

The way urban development in Athens unfolded is an outcome of relatively loose regulation, a pro-growth policy regime and a housing provision system which almost exclusively relies on private actors for housing production and land provision.

On the one hand this model of urban development reinforced some forms of social inequality (for example, unequal access to transport/mobility or to amenities like green space), but on the other hand it promoted social cohesion by making housing accessible for the vast majority of the social strata. The overall outcome of this urban development process is a city with low socio-spatial division compared to many other European metropolises [44]. According to this argument [23,34], Athens indeed has areas wherein residents with similar professional, educational and income characteristics are concentrated and overrepresented. However, the majority of the population lives in socially mixed areas, and those mixed areas cover most urban space. It therefore appears that within the Athenian context, the actions of the state that promoted social cohesion came via indirect policies, which prioritized housing provision from small private actors who were at least partly funded at the expense of public goods provision, environmental amenity, etc. A key vehicle for delivering those benefits was, and still is, the social diffusion of real property ownership [16].

The flip side of this urban development trajectory, underpinned by the housing provision system, is that "outsiders", i.e., those without a robust family support network, with limited access to political parties or unstable work circumstances, are fully exposed to the filtering and sorting function of the housing market. They therefore occupy the lower-quality dwelling stock in locations with relatively lower environmental amenity and urban infrastructure provision. Arbaci $[9,12]$ analyzed this phenomenon for foreign migrants, but it also holds true for many Roma as well as other social groups. In Athens, largely because of the urban development trajectory of the city, the least attractive dwelling stock is to be found in the lower floors of the over-developed areas of the urban core, in dwellings along the old industrial route linking Athens to Piraeus as well as in parts of the urban periphery. The concentration of migrant groups in the over-developed and socially 
mixed part of the city center corroborates Arbaci's [12] argument of the paradox of reduced segregation combined with group deprivation.

In this paper, we measure deprivation in terms of access and position in the labor market, participation in the process of education and education level, and housing conditions. Eventually, we controlled whether the patterns of deprivation are related to the spatial distribution of poor migrants in the city, but we consciously avoided using the concentration of migrants from low-income countries as a factor of and a proxy for deprivation, following the British example, and especially the work of Townsend [24,31].

The principal components analysis (PCA) has revealed two significant components that combine the initial 10 deprivation-related variables (11 for 2011) (Table 1) on the basis of their spatial variance, and in so doing they account for around $65 \%$ of the total variance of the dataset (Table 2).

Table 2. PCA eigenvalues and variance explained.

\begin{tabular}{ccccccc}
\hline \multirow{2}{*}{ Components } & \multicolumn{2}{c}{2011} & \multicolumn{2}{c}{$\mathbf{2 0 0 1}$} & \multicolumn{1}{c}{1991} \\
\cline { 2 - 6 } & Eigenvalues & \% of Variance & Eigenvalues & \% of Variance & Eigenvalues & \% of Variance \\
\hline 1 & 5.720 & 51.997 & 4.737 & 47.367 & 4.817 & 1.462 \\
2 & 1.723 & 15.666 & 1.793 & 17.931 & 0.945 & 14.618 \\
3 & 0.765 & & 0.830 & & 0.739 \\
4 & 0.673 & & 0.737 & & \\
\hline
\end{tabular}

In order to identify the content of these two principal components, it is necessary to consider their relation with the initial variables (Table 3).

Table 3. Correlation between initial variables and PCA components.

\begin{tabular}{|c|c|c|c|c|c|c|c|}
\hline \multicolumn{2}{|c|}{ PCA Initial Variables } & \multicolumn{2}{|c|}{ Components 2011} & \multicolumn{2}{|c|}{ Components 2001} & \multicolumn{2}{|c|}{ Components 1991} \\
\hline Label & Description & 1 & 2 & 1 & 2 & 1 & 2 \\
\hline Empl3 & $\begin{array}{c}\text { Managers } \\
\text { and } \\
\text { professionals }\end{array}$ & 0.872 & -0.141 & 0.845 & -0.146 & 0.796 & -0.117 \\
\hline Edu1 & $\begin{array}{l}\text { Higher } \\
\text { education } \\
\text { Up to }\end{array}$ & 0.864 & -0.297 & 0.829 & -0.396 & 0.802 & -0.139 \\
\hline Edu2 & $\begin{array}{l}\text { compulsory } \\
\text { education }\end{array}$ & 0.844 & -0.314 & 0.827 & -0.386 & 0.856 & -0.231 \\
\hline Hous2 & $\begin{array}{l}\text { Lack of } \\
\text { housing } \\
\text { space }\end{array}$ & 0.823 & 0.204 & 0.620 & 0.654 & 0.540 & 0.671 \\
\hline Edu3 & $\begin{array}{c}\text { Early school } \\
\text { dropout }\end{array}$ & 0.784 & -0.048 & 0.776 & -0.139 & 0.815 & -0.110 \\
\hline Empl2 & Unemployment & 0.741 & 0.199 & 0.480 & 0.249 & 0.555 & 0.535 \\
\hline Empl4 & $\begin{array}{c}\text { Routine } \\
\text { occupations }\end{array}$ & 0.719 & 0.465 & 0.667 & 0.465 & 0.807 & -0.177 \\
\hline Hous3 & $\begin{array}{l}\text { Tenure (rent) } \\
\text { Extreme }\end{array}$ & 0.665 & 0.610 & 0.558 & 0.700 & 0.603 & 0.540 \\
\hline Hous1 & $\begin{array}{l}\text { housing } \\
\text { conditions }\end{array}$ & 0.635 & -0.275 & 0.635 & -0.152 & 0.526 & -0.168 \\
\hline Hous4 & $\begin{array}{c}\text { Vertical } \\
\text { segregation }\end{array}$ & 0.179 & 0.635 & nd & nd & nd & nd \\
\hline Empl1 & Inactivity & 0.516 & -0.604 & 0.524 & -0.478 & 0.500 & -0.524 \\
\hline
\end{tabular}

Extraction method: principal component analysis; nd: no data.

Table 3 shows that the profiles of the two main PCA components reveal more similarities than differences among the three dates. Component 1 (C1) - the most important in terms of variance (see Table 2) - brings together all the variables that indicate social rank 
in different ways. High- and low-profile occupations, high or low education levels, and early school dropout rates are the variables mostly providing content to $\mathrm{C} 1$. Some other variables - the lack of housing space per capita and unemployment-were less related to social rank in 1991, but this relation intensified in the two following decades. The beginning of the crisis in the late 2000s and the important inflow of poor migrants since the 1990s have amplified class divisions in terms of both housing space and access to jobs.

Component 2 (C2) looks more diverse among the three dates. In 1991, it mainly brings together the lack of housing space with unemployment and tenure (rent). Since $\mathrm{C} 2$ is independent from $\mathrm{C} 1$, the relation among these three variables does not follow the spatial distribution pattern of class divisions. In fact, $\mathrm{C} 2$ indicates locations close to the city center, since it is negatively correlated with the economically inactive population whose concentration is higher in the city's periphery. In 2001, the relation between the lack of housing space and tenure is maintained, but unemployment is no longer important, due to the positive economic situation of the early 2000s linked to the preparation for the 2004 Olympic Games. Unemployment is also not important in 2011 for C2, but becomes much more important for $\mathrm{C} 1$, indicating that finding a job has become much more related to class during these 20 years. In 2011, C2 mainly brings together tenure and vertical segregation, which are both concentrated in and around the city center and mainly indicate living conditions of the migrant population: migrants are overrepresented in deprived areas of the center, but are relatively absent from peripheral areas where the inactive population is concentrated [34].

Subsequently, we used the factor scores of the two main PCA components to group the spatial units for each census year following a K-means clustering procedure. According to their General Deprivation Index (GDI), the seven clusters were divided into two high- $(\mathrm{H})$, two intermediate- (I) and three low- (L) status areas for 1991 and 2011, while for 2001 there were two low- and three intermediate-status groupings instead. Details on the profiles of all the clusters are displayed in Table 4 . Values in black $(>1.00)$ indicate scores towards more deprivation, while values in grey $(<1.00)$ indicate scores towards less deprivation. Values in bold indicate higher distance from the mean (more than $30 \%$ ).

Table 4. Profile of deprivation clusters (1991, 2001, 2011). Location quotients.

\begin{tabular}{|c|c|c|c|c|c|c|c|c|}
\hline 1991 & All & Cl1-H1 & $\mathrm{Cl2}-\mathrm{H} 2$ & $\mathrm{Cl3}-\mathrm{I} 2$ & C14-L2 & Cl5-I5 & Cl6-L1 & C17-L3 \\
\hline $\mathrm{N}$ & 2.946 & 585 & 480 & 625 & 375 & 347 & 156 & 369 \\
\hline GDI & 8.09 & 0.56 & 0.70 & 1.06 & 1.43 & 1.00 & 1.53 & 1.32 \\
\hline PCA Variables & $\%$ & & & & $\mathrm{LQ}^{*}$ & & & \\
\hline Unemployed & $\overline{3.6}$ & 0.69 & 0.94 & 0.94 & $\overline{1.22}$ & 1.25 & 1.75 & 0.86 \\
\hline Routine Occupations (30-64) & 31.5 & 0.52 & 0.62 & 1.13 & 1.51 & 0.92 & 1.47 & 1.38 \\
\hline Not in education (15-18) & 19.3 & 0.55 & 0.68 & 0.98 & 1.51 & 0.97 & 1.72 & 1.34 \\
\hline No heating system & 1.6 & 0.38 & 0.44 & 0.94 & 1.94 & 0.63 & 1.69 & 2.00 \\
\hline Tenants & 26.2 & 0.91 & 1.33 & 0.96 & 0.78 & 1.36 & 1.00 & 0.66 \\
\hline Tenants in houses with $<20 \mathrm{~m}^{2}$ per capita & 32.1 & 0.94 & 1.38 & 0.94 & 0.75 & 1.34 & 0.97 & 0.65 \\
\hline Routine occupations with $<20 \mathrm{~m}^{\frac{1}{2}}$ per capita & 49.1 & 0.73 & 0.96 & 1.05 & 1.18 & 1.11 & 1.21 & 1.00 \\
\hline $\begin{array}{c}\text { Unemployed in houses with }<20 \mathrm{~m}^{2} \text { per capita } \\
\text { Additional variables }\end{array}$ & 4.4 & 0.70 & 1.02 & 0.91 & 1.16 & 1.30 & 1.70 & 0.84 \\
\hline Migrants from developed economy countries & 1.2 & 1.58 & 1.33 & 0.67 & 0.75 & 0.83 & 1.33 & 0.58 \\
\hline Migrants from developing countries & 0.9 & 1.11 & 1.67 & 0.56 & 0.56 & 1.56 & 1.33 & 0.56 \\
\hline 2001 & All & C11-I2 & C12-I3 & Cl3-L1 & $\mathrm{Cl} 4-\mathrm{H} 2$ & Cl5-H1 & Cl6-I1 & C17-L2 \\
\hline $\mathrm{N}$ & 2.969 & 276 & 311 & 318 & 530 & 1.254 & 93 & 187 \\
\hline GDI & 6.07 & 1.20 & 1.21 & 1.87 & 0.79 & 0.63 & 1.14 & 1.84 \\
\hline PCA Variables & $\underline{\%}$ & & & & LQ & & & \\
\hline Unemployed & $\overline{5.4}$ & 1.20 & 0.87 & 1.59 & 1.07 & 0.78 & 1.15 & 1.37 \\
\hline Routine occupations (30-64) & 13.1 & 1.13 & 0.90 & 1.98 & 0.93 & 0.64 & 1.66 & 1.53 \\
\hline Not in education (15-18) & 13.5 & 1.21 & 1.23 & 1.68 & 0.80 & 0.63 & 1.16 & 1.80 \\
\hline No heating system & 3.3 & 1.39 & 1.42 & 2.21 & 0.67 & 0.55 & 0.88 & 2.09 \\
\hline Tenants & 24.8 & 0.99 & 0.77 & 1.08 & 1.19 & 0.93 & 1.52 & 0.66 \\
\hline Tenants in houses with $<20 \mathrm{~m}^{2}$ per capita & 33.8 & 1.01 & 0.79 & 1.09 & 1.22 & 0.89 & 1.55 & 0.67 \\
\hline Routine occupations with $<20 \mathrm{~m}^{\frac{1}{2}}$ per capita & 19.0 & 1.06 & 0.83 & 1.64 & 1.04 & 0.74 & 1.61 & 1.29 \\
\hline Unemployed in houses with $<20 \mathrm{~m}^{2}$ per capita & 5.7 & 1.23 & 0.86 & 1.53 & 1.12 & 0.75 & 1.11 & 1.37 \\
\hline Additional variables & $\underline{\%}$ & & & & LQ & & & \\
\hline Migrants from developed economy countries & $\overline{1.1}$ & 0.64 & 0.36 & 0.91 & 1.36 & 1.27 & 1.27 & 0.36 \\
\hline Migrants from developing countries & 7.4 & 1.05 & 0.74 & 1.72 & 1.11 & 0.61 & 2.27 & 0.96 \\
\hline
\end{tabular}


Table 4. Cont.

\begin{tabular}{|c|c|c|c|c|c|c|c|c|}
\hline 2011 & All (\%) & Cl1-H1 & $\mathrm{Cl} 2-\mathrm{H} 2$ & C13-L2 & C14-L1 & Cl5-L3 & Cl6-I1 & C17-I2 \\
\hline $\mathrm{N}$ & 2.999 & 1.406 & 116 & 370 & 384 & 267 & 147 & 309 \\
\hline GDI & 6.09 & 0.62 & 0.94 & 1.80 & 1.97 & 1.63 & 1.20 & 1.18 \\
\hline PCA Variables & $\%$ & & & & LQ & & & \\
\hline Unemployed & $\overline{13.9}$ & 0.78 & 1.06 & 1.45 & 1.36 & 1.37 & 1.00 & 1.17 \\
\hline Routine occupations (30-64) & 9.0 & 0.64 & 1.09 & 1.82 & 1.70 & 2.22 & 0.96 & 1.07 \\
\hline Not in education (15-18) & 6.4 & 0.58 & 0.88 & 1.72 & 2.83 & 1.84 & 1.08 & 1.09 \\
\hline No heating system & 3.7 & 0.41 & 0.76 & 2.14 & 3.11 & 0.84 & 1.51 & 1.41 \\
\hline Tenants & 24.4 & 0.92 & 1.27 & 1.06 & 0.66 & 1.87 & 0.74 & 0.95 \\
\hline Tenants in houses with $<20 \mathrm{~m}^{2}$ per capita & 30.3 & 0.66 & 1.05 & 1.58 & 1.64 & 1.55 & 1.15 & 1.22 \\
\hline Routine occupations with $<20 \mathrm{~m}^{2}$ per capita & 34.5 & 0.78 & 1.15 & 1.36 & 1.32 & 1.43 & 1.00 & 1.13 \\
\hline Unemployed in houses with $<20 \mathrm{~m}^{2}$ per capita & 27.0 & 0.70 & 1.10 & 1.49 & 1.47 & 1.53 & 1.07 & 1.19 \\
\hline Residents in basements and ground floors & 8.5 & 0.85 & 1.46 & 1.11 & 0.56 & 1.82 & 0.72 & 1.05 \\
\hline Additional variables & $\%$ & & & & LQ & & & \\
\hline Migrants from developed economy countries & 1 & 1.20 & 1.20 & 0.60 & 0.40 & 2.70 & 0.50 & 0.60 \\
\hline Migrants from developing countries & 9.2 & 0.58 & 1.25 & 1.79 & 1.15 & 3.48 & 0.80 & 0.99 \\
\hline
\end{tabular}

* Note: Location quotients are the percentages of each variable-or the value of General Deprivation Index (GDI)-in each cluster divided by the respective percentage-or GDI-in all clusters. The first three digits in the column labels denote cluster numbers (Cl1 to Cl7). The last two digits denote the social profile of the cluster (H: high; I: intermediate; L: low) and the subdivision within each profile (1 to 3). Table S4 (Supplementary Materials) provides a full legend on the profiles of depicted clusters.

Table 4 shows that the three most deprived clusters in $1991(6,4$ and 7$)$ have very similar features, and do not contain areas where tenants are over-concentrated. The two clusters where tenants are overrepresented (5 and 2) are intermediate- and high-status areas with some deprivation problems related mainly to their tenant population. In 2001, the deprived areas are mainly concentrated in two clusters ( 3 and 7), both comprising neighborhoods of the city center where the share of tenants is low. Deprivation in central neighborhoods is affecting part of the population-mainly tenants and routine occupations-in one of the intermediate clusters (6), where the share of tenants is the highest. In 2011, however, the three low-status clusters $(3,4$ and 5) comprise peripheral areas reproducing the same pattern of deprivation as in the previous two decades, but also a cluster of central city neighborhoods with a high concentration of tenants, which exhibits for the first time indices of deprivation that are equal, and sometimes higher, than those of peripheral deprivation areas. These clusters are represented in deprivation maps for the three dates (Figures 3-5). Some clusters with low levels of deprivation have been merged to simplify the overall pattern, while those closer to deprivation are the same as in Table 4. Deprivation maps for the three dates (Figures 3-5) show three things: (1) Deprivation is persistently present in specific parts of the city's periphery, mainly in the west and the outer peripheral zone. (2) Deprivation has rapidly grown in neighborhoods of the city center that changed from high-status in 1991 to intermediate in 2001 and low-status in 2011. (3) A considerable number of traditional working-class areas within the Attica basin have considerably improved their relative position in terms of deprivation. The data for 2001 show that it was a transition period of decline in central neighborhoods, and improvement in working class suburbs. This transition is confirmed by the pattern of deprivation in 2011. This specific finding concurs with a recent analysis on the changing social profile of the city's neighborhoods [45], while the overall results are in broad alignment with the findings of other contemporary alternative explorations of deprivation in Athens [14,20,21].

In order to consolidate the changes observed on Figures 3-5, we quantified the changes of status of the spatial units (URANU) involved in our previous analysis for 1991 and 2011. Table 5 and Figure 6 show that most of the low deprivation (i.e., high social status) areas in 2011 were also of lower or intermediate deprivation in 1991 (over 90\%). On the opposite side, the high deprivation areas of clusters 3 and, mainly, 4 are indicative of the persistence of deprivation in pockets of poverty at the outskirts of the city. These are the strongholds of deprivation and they have been reproduced as such during this 20 year period. The next important item in this table is that some areas of high deprivation in 2011 (cluster 5) originate almost exclusively from areas that were either of low or intermediate deprivation status in 1991. This indicates the fast decline of city center neighborhoods through filtering-down. Finally, most of the intermediate status areas in 2011 originate 
from high deprivation ones. This indicates the massive improvement of living conditions and the changing of social profile from working-class to socially mixed in the traditional working-class part of the city. This process is related to improvement through endogenous social mobility [37], whereas gentrification is completely absent from that part of the city. Figure 6 provides a summarized view of the changes between 1991 and 2011, depicting the high/intermediate/low deprivation areas of 1991 related to their remaining in the same deprivation category or their upgrading or downgrading. The areas in red in this figure indicate areas that either remained or became high deprivation areas in these 20 years. Their double pattern clearly reveals the persistent deprivation in clusters of the city's periphery and the emergence of a significant new deprivation cluster in the city center.

Table 5. Distribution of Athenian spatial units (URANU) within the 2011 deprivation clusters by their respective deprivation status in 1991.

\begin{tabular}{ccccccccc}
\hline Clusters & \multicolumn{9}{c}{ Status 2011 } \\
\hline Status 1991 & All & Cl1-H1 & Cl2-H2 & Cl3-L2 & Cl4-L1 & Cl5-L3 & Cl6-I1 & Cl7-I2 \\
\hline N & 2.999 & 1.406 & 116 & 370 & 384 & 267 & 147 & 309 \\
High & 35.6 & 59.5 & 44.0 & 1.9 & 0.0 & 48.4 & 1.0 & 2.4 \\
Intermediate & 33.3 & 31.4 & 47.3 & 25.9 & 2.6 & 47.7 & 20.2 & 42.6 \\
Low & 31.1 & 9.0 & 8.7 & 72.2 & 97.4 & 3.9 & 78.8 & 54.9 \\
\hline
\end{tabular}

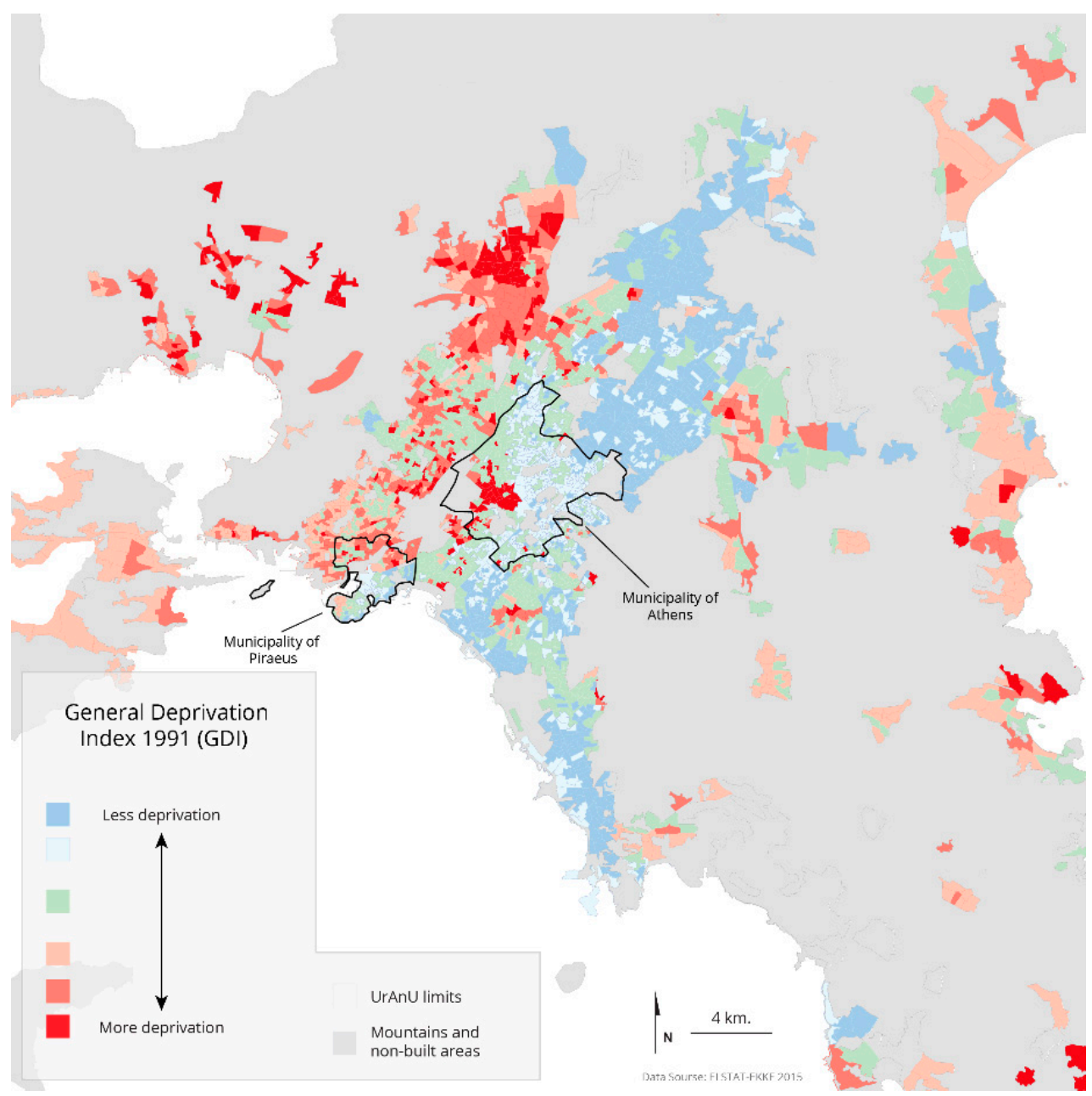

Figure 3. Clusters of deprivation in Athens (1991). 


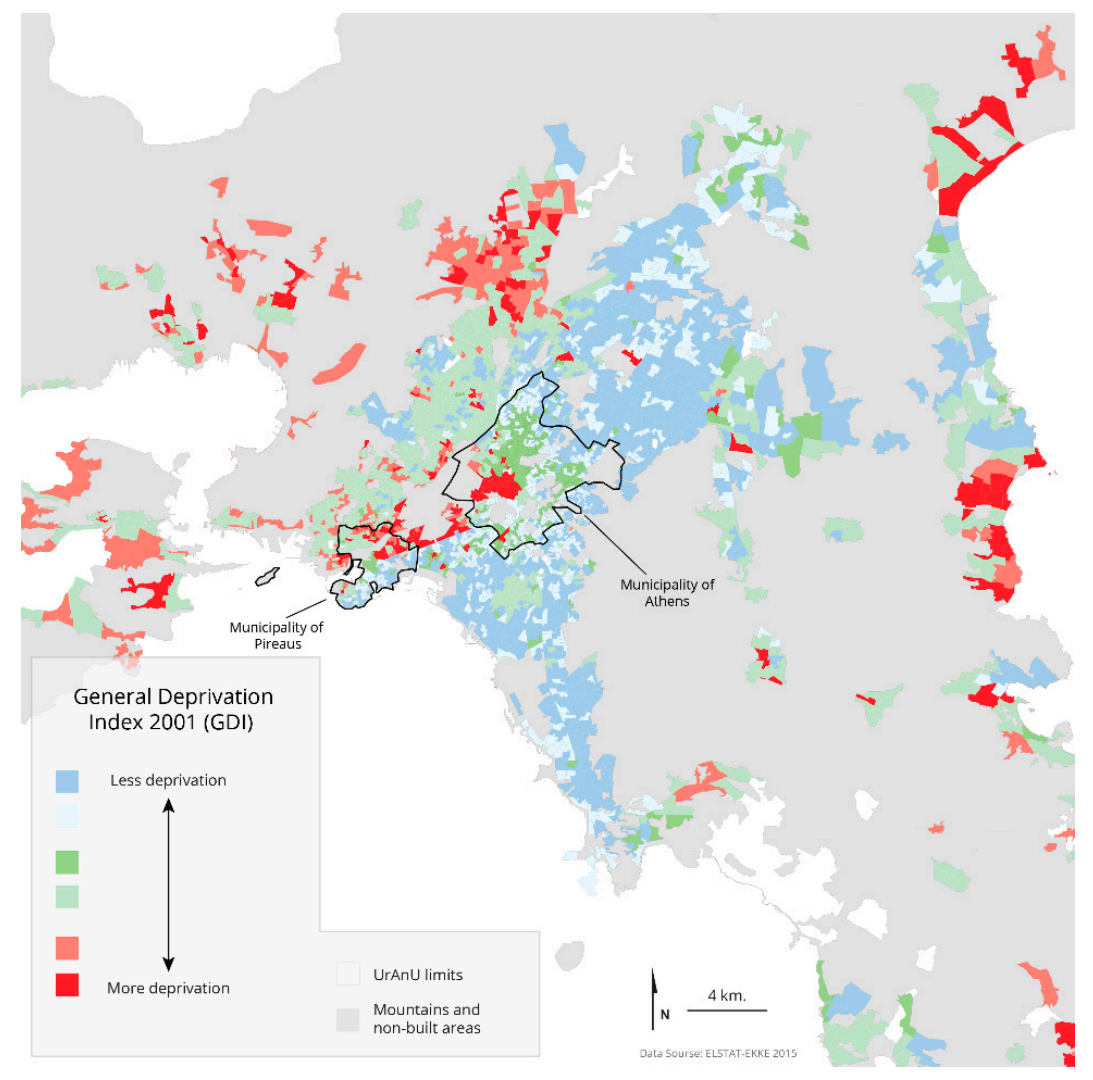

Figure 4. Clusters of deprivation in Athens (2001).

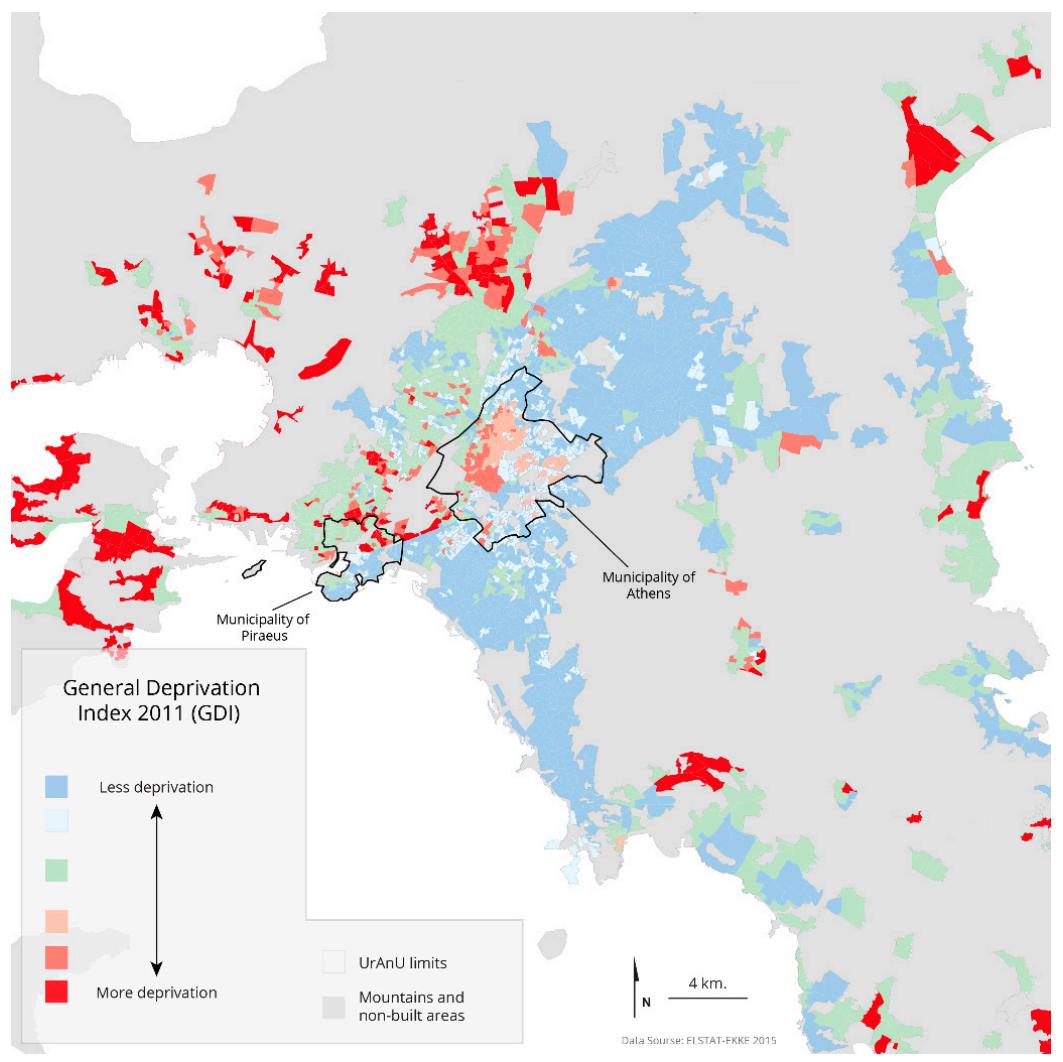

Figure 5. Clusters of deprivation in Athens (2011). 


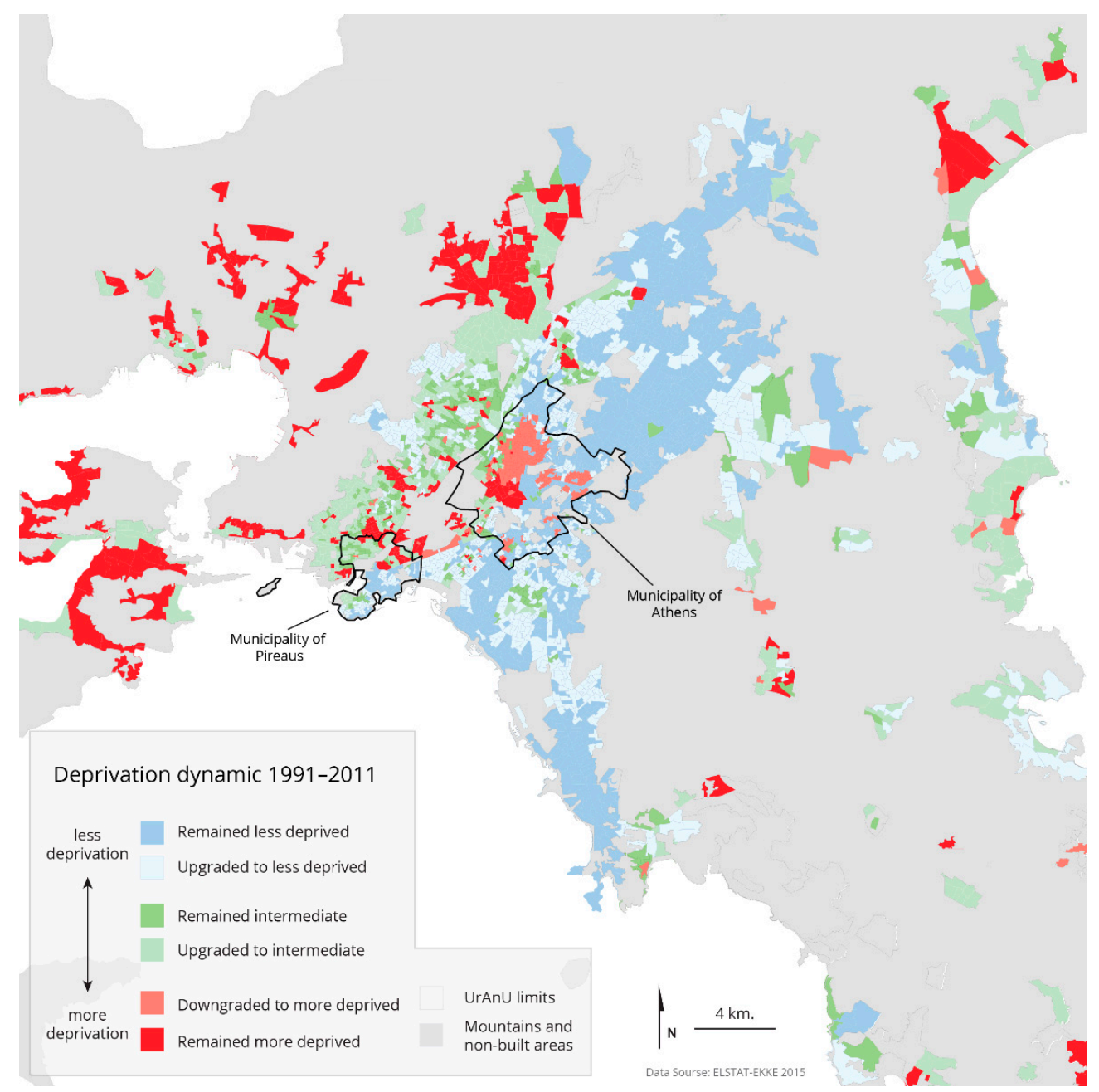

Figure 6. Change of deprivation status in Athens (1991-2011).

To conclude the exploration of deprivation in Athens between 1991 and 2011, we examined the evolution of the GDI by decile. For each year, we calculated this index by decile and - to make them comparable - we used for each decile the quotient of its GDI by the overall GDI. It is noteworthy that not only has the overall GDI increased, but also the concentration of deprivation, as measured by the LQ, in the most deprived areas has increased as well. Figure 7 shows these decile quotients for the three census years. At the top end (first decile), changes were very limited. The GDI improved considerably in areas in the middle of the distribution-especially between the third and sixth decile during the 1990s. Changes were also limited at the lower end (deciles seven and eight), but they were particularly negative at the lower extremity (ninth decile) where the GDI increased considerably between 1991 and 2011.

When information about the nationality/migration profile of deprivation clusters is introduced (Table 4), it becomes clear that there were significant changes between 1991 and 2011. There were few poor migrants in 1991, mainly gathered in high and intermediate status areas as personnel in domestic services. Their presence increased more than 10-fold in 20 years. Meanwhile, their spatial distribution became concentrated in declining central neighborhoods (3.5 times the average share) and in some low-status neighborhoods of the periphery (1.8 times the average share). Poor migrant groups have concentrated in the less attractive parts of the city and in the lower-quality housing stock. 


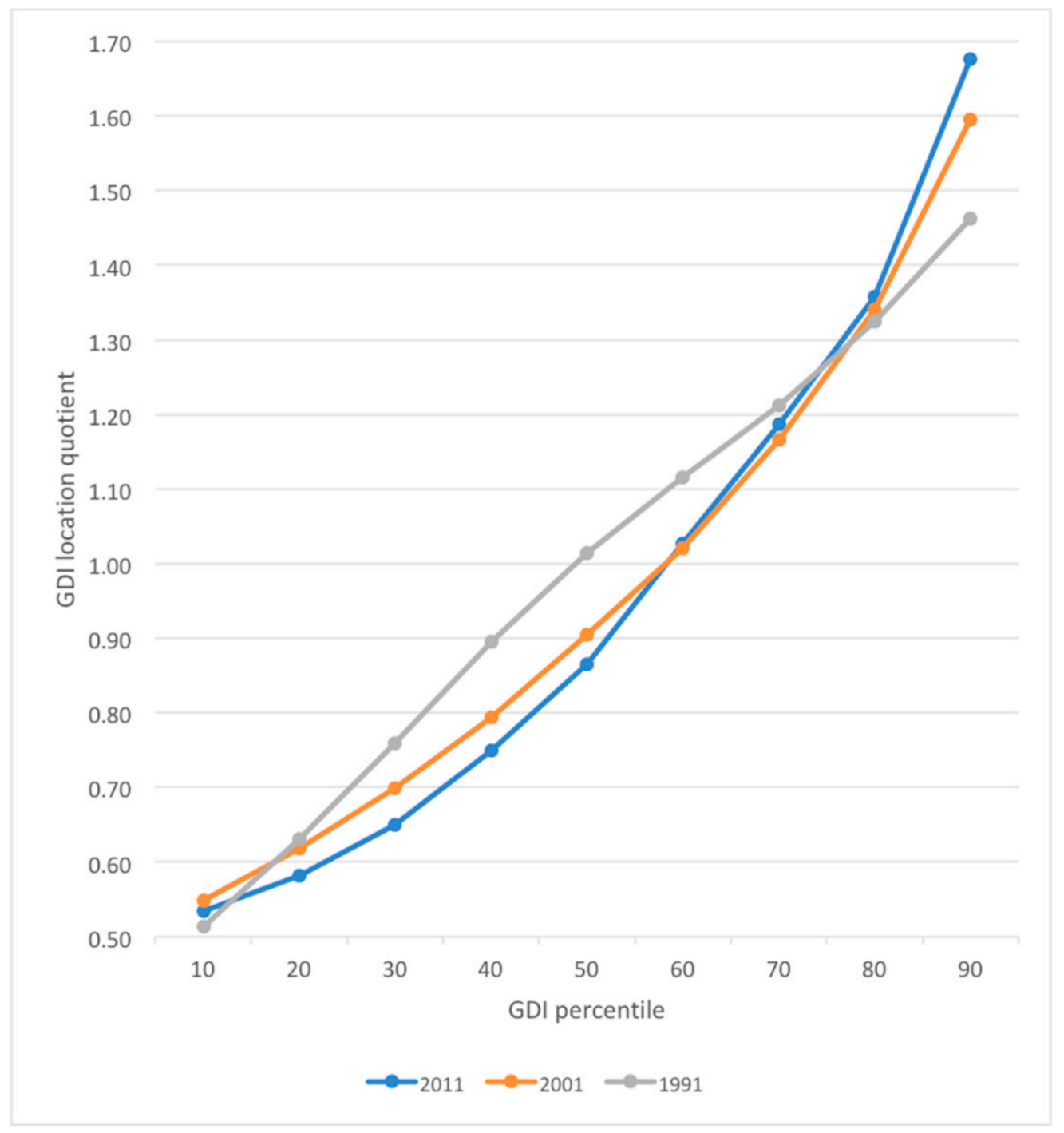

Figure 7. General Deprivation Index in Athens by decile (1991-2011).

Said areas are mainly in the periphery of Attica, in the old industrial core between Athens and Piraeus and at the western borders of the Municipality of Athens. They include the peripheral areas where Roma groups, as well as Greek repatriates from the former Soviet republics and immigrants from India, Pakistan and Bangladesh, reside. The peripheral locales of deprivation have significantly higher concentrations of irregular housing, compared to the rest of the metropolis, where it is almost absent.

The areas of the city center where multiple deprivation has worsened have not faced significant deterioration in their physical condition between 1991 and 2011, but in some cases probably the contrary applies. However, they attract tenants whose employment, income and housing conditions got worse during that period. The accumulation of employment and housing disadvantage is high for long-established migrants, who lost their jobs in construction, manufacturing and service industries, and also for newcomers, asylum seekers and refugees in central areas. It appears therefore that multiple deprivation in Athens is linked to processes of filtering and sorting in the labor and housing markets. Greek households try to mitigate these filtering and sorting pressures using family-based strategies spanning across generations [17]. However, newcomers to the city (and the country) are comparatively more exposed to market forces. 


\section{Conclusions}

The analysis in this paper confirms the findings of previous research about the concentration of poverty [20] and the role of housing systems in the social geography of the city $[12,38]$. What is more, the paper shows how Athens' spatial patterns of deprivation appear to be tied to its urban development trajectory via the way that the city residents access housing. The explosive population growth of the city in the post-war period gave rise to a mode combining expansion and intensification. The result was a high-density city with a relatively limited provision of environmental amenity, especially in the areas housing the less affluent strata. It is in the old industrial core along the Athens-Piraeus axis, around the gulf of Elefsina, the port of Lavrion (another old industrial location) and several peripheral locations in Attica, where deprivation is historically concentrated, according to the analysis in this paper. The trend towards suburbanization in the 1980s, 1990s and 2000s eventually gave rise to a city-center cluster of deprivation, as the middle classes left the city center and relocated to the northeastern and southeastern suburbs. Such "unequal growth" and longer-term processes in operation after 1991 have caused spatial and social inequalities to deepen. Insofar as housing is concerned, the real estate boom, and the economic changes induced by the centrally planned restructuring of the city in the preparation for the Olympics, mostly favored the already privileged city areas $[35,46]$.

It is interesting to note, however, that a significant part of the traditional working-class areas in western Athens fares relatively well, meaning that the familial nature of welfare provision in Greece [10] proved to be effective. In these traditional working-class areas of Athens, a large part of their socially mobile younger generations remained in situ, inducing a trajectory of decreasing deprivation for these areas during the 1990s, and proved resilient to the most detrimental consequences of the debt crisis.

Crucially, it appears that the populations for which the situation significantly worsened between 1991 and 2011, and especially after 2001, are those who are marginalized and thus excluded from access to real property ownership, or can only access the housing market from a significantly disadvantaged position. The deprivation score increased in inner city areas and peripheral working-class areas, and not in suburban working-class areas. This may also be a spatial indication of the changing composition of the working class, and its internal differentiation and ability to cope with precariousness along ethnic and generational lines. Especially affected are the areas in the center and to the west and south of the Municipality of Athens. The conditions have also deteriorated in peri-urban areas of sprawl, suggesting the negative effects of unplanned growth [47-49]. Having said that, the fact that populations in the old industrial city quarters and Lavrion have persistently been affected by multiple deprivation also stands testament to the effects that de-industrialization and the debt crisis had on the social and physical fabric of the metropolis.

Measuring deprivation in the Greek context, even insofar as Athens was concerned, proved to be difficult mainly due to two factors: the lack of detailed relevant data and the lack of an appropriate survey that would allow us to establish an adequate understanding of "perceived" deprivation. The three censuses used cover a wide range of topics, and some key trends can be explored, albeit the range of variables covered less ground than optimally required. Still, analyzing the social and physical fabric of Athens in terms of a multidimensional understanding of deprivation may allow policy to be more effective in the future. Given the nature of the phenomenon of multiple deprivation and its geographical patterns in Athens, it would be important for the State to develop new mechanisms that would be able to direct the limited resources available in a more targeted, efficient and effective way to people in need. Moreover, deprivation in this paper is understood as a distinctive feature among neighborhoods. The resulting configuration of deprivation-especially the cluster in high-rise areas of the center-as well as the literature on vertical segregation in Athens [7], reveal the need to study deprivation patterns also within neighborhoods. The study of the patterns and the impact of micro-segregation within neighborhoods is not 
particular for Athens, but applies to the large number of cities where micro-segregation is important but usually understudied.

Within the context of ongoing economic stagnation and rising urban poverty, measuring urban deprivation and coming forward with policies for urban regeneration in Athens is more pertinent than ever. In much of western Europe, area-based regeneration policies emphasize social mixing, and housing provision is one of the vehicles used to achieve it [50]. Evidence shows that the success of such approaches appears to be context-specific and that, actually, social homogeneity may occasionally also be effective in achieving poverty reduction [51]. In some cases, it clearly emerges that mixing does not reduce poverty [52,53], and Athens is one of those cases, according to a recent paper on unequal educational attainment in the most socially mixed neighborhoods of the city [45]. Area-based policies have to be combined with policies targeting groups in need within a broader social policy plan. Both such components are missing in the Greek context, where emergency haphazard measures continue to be utilized in order to address permanent problems.

In an interesting development, at present, parts of the city center attract investment interest mainly from the tourist and leisure industries. There is evidence that several central areas were affected by touristification and the explosive growth of the short-term rental sector $[8,54]$. It remains to be seen what the future will hold in the post-pandemic era, but it is likely that the best dwelling stock in the city center will continue to be available as short-term rentals and, at the same time, pressure for reconversion to short-term rental will continue for the city center's affordable stock. This is bound to put the most vulnerable tenants in danger of displacement. Policy responses trying to address this trend were limited in scale and scope. The crisis in tourism during the pandemic has put the issue on the backburner. However, now would be the time to think about policies that would be difficult to implement when tourism in Athens recovers from the pandemic.

These findings pose serious challenges for the applicability of area-based initiatives in metropolitan Athens, in the form in which they are carried out at present. The mechanism through which multiple deprivation in the city became spatially concentrated is related to the operation of the housing market, reinforced by labor market dynamics: access to the housing market, income poverty, unemployment and lack of skills are the key issues that can be effectively addressed by national and sectoral policies. However, there is scope for area-based policies to focus not only on central but also on peripheral areas, to provide housing for those without access to homeownership and to improve social and physical infrastructure in areas where it is lacking, and especially in areas of irregular housing. Unless issues like unemployment, education and access to housing are dealt with, areabased approaches and regeneration plans in metropolitan Athens run the risk of displacing the populations most affected by multiple deprivation, without addressing their needs, the structural forces, and the discriminating practices which tend to marginalize them.

The city has been able to function in spite of inefficient urban policies since the second half of the 20th century. However, it is unlikely that the city will be able to manage future challenges in a fair way without a serious attempt to address current socio-spatial imbalances. The introduction of an urban observatory and an index of deprivation, as in many other European cities [55,56], could be extremely helpful to deliver evidence-based policies and tackle the complex issues of deprived areas.

Supplementary Materials: The following are available online at https://www.mdpi.com/2073-4 45X/10/3/290/s1, Figure S1. Age of dwelling stock: Percentage of residents living in dwellings built during a range of construction periods (2011); Figure S2. Percentage of residents living in apartment blocks, in the Athens metropolitan area, by URANU (2011); Figure S3. Clusters of deprivation in Athens (1991) Figure S4. Clusters of deprivation in Athens (2001); Figure S5. Clusters of deprivation in Athens (2011); Figure S6. Change of deprivation status in Athens (1991-2011); Figure S7. General Deprivation Index in Athens by decile (1991-2011); Table S1. Deprivation variables; Table S2. PCA eigenvalues and variance explained; Table S3. Correlation between initial variables and PCA components; Table S4. Profile of deprivation clusters (1991, 2001, 2011). Location quotients, 
Table S5. Distribution of Athenian spatial units (URANU) within the 2011 deprivation clusters by their respective deprivation status in 1991.

Author Contributions: Conceptualization, N.K. and T.M.; data curation, T.M.; formal analysis, T.M. and V.P.A.; methodology, N.K., T.M. and V.P.A.; visualization, T.M.; writing-original draft, N.K. and T.M.; writing - review and editing, N.K., T.M. and V.P.A. All authors have read and agreed to the published version of the manuscript.

Funding: This research received no external funding.

Institutional Review Board Statement: Not applicable.

Informed Consent Statement: Not applicable.

Data Availability Statement: The datasets used in this paper can be directly accessed in the repository of the SoDaNet network (Greek research infrastructure for the social sciences) of the National Centre for Social Research (http:/ / www.ekke.gr, accessed on 3 November 2020) part of the CESSDA ERIC (https:/ / www.cessda.eu/, accessed on 3 November 2020).

Acknowledgments: Our dear colleague John Sayas, professor at NTUA (National Technical University of Athens), who unfortunately passed away last summer, has contributed to writing this paper like the rest of us and should be cited among the authors. However, editorial rules do not allow this because obtaining his consent for publication was no longer possible when the paper was completed. This article was partly inspired by and based on debates and research conducted in the project ISTOPOL (2020-2022) funded by the Hellenic Foundation for Research \& Innovation (HFRI) under grant agreement HFRI-FM17-1183 (26/03/2020). We thank Stavros Spyrellis of the National Centre for Social Research (EKKE) for editing the maps of this paper.

Conflicts of Interest: The authors declare no conflict of interest.

\section{References}

1. Emmanuel, D. Socioeconomic inequalities and housing in Athens: Impacts of the monetary revolution of the 1990s. Greek Rev. Soc. Res. 2004, 113, 121-143.

2. Chorianopoulos, J.; Pagonis, T. In the Traces of the Mediterranean City. Urbanity, Planning and Governance in the Athenian Metropolis; Kritiki: Athens, Greece, 2020. (In Greek)

3. Maloutas, T. The Archaeology of the Decline of the City Center: Residential Location Choices of Affluent Groups. In Remapping Crisis: A Guide to Athens; Tsilimpounidi, M., Walsh, A., Eds.; Zero Books: London, UK, 2014; pp. $26-42$.

4. Maloutas, T. The Social Geography of Athens. Social Groups and the Built Environment of a South European Metropolis; Alexandria: Athens, Greece, 2018. (In Greek)

5. President of the Hellenic Republic. Law 1515 for the Regulatory Plan and Environmental Protection Programme for the wider Athens area. Gov. Gaz. 1985, 18A, 361-398.

6. Balampanidis, D. Housing Pathways of Immigrants in the City of Athens: From Homelessness to Homeownership. Considering Contextual Factors and Human Agency. Hous. Theory Soc. 2019, 37, 230-250. [CrossRef]

7. Maloutas, T.; Karadimitriou, N. Vertical Social Differentiation in Athens: Alternative or Complement to Community Segregation? Int. J. Urban Reg. Res. 2001, 25, 699-716. [CrossRef] [PubMed]

8. Maloutas, T.; Spyrellis, S.N. Inequality and segregation in Athens: Maps and data. In Athens Social Atlas; Maloutas, T., Spyrellis, S., Eds.; Digital compendium of texts and visual material; 2019; Available online: https:/ /www.athenssocialatlas.gr/en/article/ inequality-and-segregation-in-athens / (accessed on 3 November 2020).

9. Arbaci, S. (Re)Viewing Ethnic Residential Segregation in Southern European Cities: Housing and Urban Regimes as Mechanisms of Marginalisation. Hous. Stud. 2008, 23, 589-613. [CrossRef]

10. Allen, J.; Barlow, J.; Leal, J.; Maloutas, T.; Padovani, L. Housing and Welfare in Southern Europe; Blackwell Publishing: Oxford, UK, 2004.

11. Kandylis, G. Urban Formation and Migration. The Social Reproduction of Thessaloniki from the Side of Labour. Ph.D. Thesis, Department of Planning, University of Thessaly, Volos, Greece, 2005. (In Greek).

12. Arbaci, S. Paradoxes of Segregation: Housing Systems, Welfare Regimes and Ethnic Residential Change in Southern European Cities; John Wiley and Sons: Hoboken, NJ, USA, 2019.

13. D' Ambrosio, C.; Papadopoulos, F.; Tsakloglou, P. Social Exclusion in EU Member States: A comparison of two alternative approaches. In Proceedings of the XVI Annual Conference of the European Society of Population Economics, Bilbao, Spain, 13 June 2002.

14. Arapoglou, V.P.; Karadimitriou, N.; Maloutas, T.; Sayas, J. Multiple deprivation in Athens: A legacy of persisting and deepening spatial divisions. In GreeSE Papers; Hellenic Observatory, LSE: London, UK, 2021. 
15. Tsoulouvis, L. Urban Planning, Social Policy and New Forms of Urban Inequality and Social Exclusion in Greek Cities. Int. J. Urban Reg. Res. 1996, 20, 718-732. [CrossRef]

16. Karadimitriou, N.; Pagonis, T. Planning reform and development rights in Greece: Institutional persistence and elite rule in the face of the crisis. Eur. Plan. Stud. 2019, 27, 1217-1234. [CrossRef]

17. Maloutas, T. Housing and Family in Athens: An Analysis of Post-war Housing Practice; Exantas: Athens, Greece, 1990. (In Greek)

18. Leontidou, L. Cities of Silence. Working-Class Settlements in Athens and Piraeus, 1909-1940; Piraeus Bank Group Cultural Foundation: Athens, Greece, 1989.

19. Kalfa, K. Self-Promotion Now! The Invisible Side of US Assistance to Greece; Futura: Athens, Greece, 2019. (In Greek)

20. Panori, A. A Tale of Hidden Cities. Region 2017, 4, 19-38. [CrossRef]

21. Panori, A.; Ballas, D.; Psycharis, Y. SimAthens: A spatial microsimulation approach to the estimation and analysis of small area income distributions and poverty rates in the city of Athens, Greece. Comput. Environ. Urban Syst. 2017, 63, 15-25. [CrossRef]

22. Leontidou, L. The Mediterranean City in Transition; CUP: Cambridge, UK, 1990.

23. Maloutas, T. Segregation, social polarization and immigration in Athens during the 1990s: Theoretical expectations and contextual difference. Int. J. Urban Reg. Res. 2007, 31, 733-758. [CrossRef]

24. Townsend, P. Poverty in the United Kingdom; Allen Lane and Penguin Books: London, UK, 1979.

25. Townsend, P.; Gordon, D. What is enough? The definition of a poverty line. In The International Analysis of Poverty; Townsend, P., Ed.; Harvester Wheatsheaf: London, UK, 1993; pp. 40-78.

26. Gordon, D.; Pantazis, C. (Eds.) Breadline Britain in the 1990s; Summerleaze House Books: Bristol, UK, 1997.

27. Levitas, R.; Pantazis, C.; Gordon, D.; Lloyd, E.; Patsios, D. The Multi-Dimensional Analysis of Social Exclusion; DCLG: London, UK, 2007.

28. Pantazis, C.; Gordon, D.; Levitas, R. Poverty and Social Exclusion in Britain; The Policy Press: Bristol, UK, 2006.

29. Hillyard, P.; Kelly, G.; McLaughlin, E.; Patsios, D.; Tomlinson, M. Bare Necessities. Poverty and Social Exclusion in Northern Ireland: Key Findings; Democratic Dialogue: Belfast, UK, 2003.

30. CLG-Communities and Local Government. The English Indices of Deprivation 2010; CLG: London, UK, 2011.

31. Nolan, B.; Whelan, C. Using Non-Monetary Deprivation Indicators to Analyze Poverty and Social Exclusion: Lessons from Europe? J. Policy Anal. Manag. 2010, 29, 305-325. [CrossRef]

32. Katsikas, I. The social content of the land-for-flats system and its economic ramifications. Greek Rev. Soc. Res. 2000, 103Г, 3-26. (In Greek)

33. Sayas, J.P. An exploration of the social and spatial division of labour in the Athenian urban space. Greek Rev. Soc. Res. 2004, 113, 167-206. [CrossRef]

34. Maloutas, T.; Spyrellis, S.N. Segregation trends in Athens: The changing residential distribution of occupational categories during the 2000s. Reg. Stud. 2020, 54, 462-471. [CrossRef]

35. Souliotis, N.; Sayas, J.; Maloutas, T. Megaprojects, neoliberalization and state capacities: Assessing the medium-term impact of the 2004 Olympic Games on Athenian urban policies. Environ. Plan. C Gov. Policy 2014, 32, 731-745. [CrossRef]

36. ELSTAT [Greek Statistical Authority]. Construction Activity Statistics. 2019. Available online: http://www.statistics.gr/el/ statistics/- / publication/SOP03/ (accessed on 23 March 2019).

37. Maloutas, T. Segregation and spatial mobility. Spatially entrapped social mobility and its impact on segregation in Athens. Eur. Urban Reg. Stud. 2004, 11, 195-211. [CrossRef]

38. Maloutas, T.; Balampanidis, D.; Siatitsa, D. Access to housing and social inclusion in a post-crisis era: Contextualizing recent trends in the city of Athens. Soc. Incl. 2020, 8/3, 5-15. [CrossRef]

39. Kandylis, G.; Maloutas, T.; Sayas, J. Immigration, inequality and diversity: Socio-ethnic hierarchy and spatial organization in Athens, Greece. Eur. Urban Reg. Stud. 2012, 19, 267-286. [CrossRef]

40. Maloutas, T. Housing provision models and family strategies in Greece. In The Challenge of Social Policy Reform in the XXI Century: Towards Integrated Systems of Social Protection; Carlos, M.R., d'Assunção, P., Eds.; I.Sideris: Athens, Greece, 2008 ; pp. $311-329$.

41. Economou, D. Housing Policy in Post-war Greece. Rev. Soc. Res. 1987, 64, 56-129. (In Greek)

42. Economou, D. Land and housing system. In The Problems of Welfare State Development in Greece; Maloutas, T., Economou, D., Eds.; Exandas: Athens, Greece, 1988. (In Greek)

43. Tsoulouvis, L. Planning, the urban system and new forms of inequality in Greek cities. Prog. Plan. 1998, 50, 3-74. [CrossRef]

44. Marcińczak, S.; Musterd, S.; van Ham, M.; Tammaru, T. Inequality and rising levels of socio-economic segregation: Lessons from a pan-European comparative study. In East Meets West: New Perspectives on Socio-Economic Segregation in European Capital Cities; Tammaru, T., Marcińczak, S., van Ham, M., Musterd, S., Eds.; Routledge: London, UK, 2016; pp. 358-382.

45. Maloutas, T.; Botton, H. Social Polarization and Segregation in Athens: Social Changes in Different Types of Residential Space between 1991 and 2011. Soc. Incl. 2021, 9. [CrossRef]

46. Salvati, L. Neither ordinary nor global: A reflection on the 'extra-ordinary'expansion of Athens. Urban Plan. Transp. Res. 2014, 2, 49-56. [CrossRef]

47. Arapoglou, V.P.; Sayas, J. New facets of urban segregation in southern Europe: Gender, migration and social class change in Athens. Eur. Urban Reg. Stud. 2009, 16, 345-362. [CrossRef]

48. Chorianopoulos, I.; Tsilimigkas, G.; Koukoulas, S.; Balatsos, T. The shift to competitiveness and a new phase of sprawl in the Mediterranean city: Enterprises guiding growth in Messoghia-Athens. Cities 2014, 39, 133-143. [CrossRef] 
49. Salvati, L.; Zitti, M. Sprawl and mega-events: Economic growth and recent urban expansion in a city losing its competitive edge (Athens, Greece). Urbani Izziv 2017, 28, 110-121. [CrossRef]

50. Karadimitriou, N.; De Magalhaes, C.; Verhage, R. Planning, Risk and Property Development: Urban Regeneration in England, France and the Netherlands; Routledge: Abingdon, UK, 2013.

51. Galster, G. Neighbourhood Social Mix as a Goal of Housing Policy: A Theoretical Analysis. Eur. J. Hous. Policy 2007, 7, 19-43. [CrossRef]

52. Blanc, M. The Impact of Social Mix Policies in France. Hous. Stud. 2010, 25, 257-272. [CrossRef]

53. Ostendorf, W.; Musterd, S.; De Vos, S. Social Mix and the Neighbourhood Effect: Policy Ambitions and Empirical Evidence. Hous. Stud. 2001, 16, 371-380. [CrossRef]

54. Balampanidis, D.; Maloutas, T.; Papatzani, E.; Pettas, D. Informal urban regeneration as a way out of the crisis? Airbnb in Athens and its effects on space and society. Urban Res. Pract. 2019, 1-20. [CrossRef]

55. Córdoba Hernandez, R.; García, I.G.; Periñan, G.G. Urban Poverty Partnership: Report about Urban Deprivation/Poverty Observatories in the European Union. Info: Eu-Repo/Semantics/Other. 2018. Available online: https://ec.europa.eu/ futurium/en/urbanpoverty/report-about-urban-deprivationpoverty-observatories-eu-universidad-politecnica-de (accessed on 3 November 2020).

56. Guillaume, E.; Pornet, C.; Dejardin, O.; Launay, L.; Lillini, R.; Vercelli, M.; Launoy, G. Development of a cross-cultural deprivation index in five European countries. J. Epidemiol. Community Health 2016, 70, 493-499. [CrossRef] [PubMed] 